\title{
Conceptualising online fashion brand recognition: scale development and validation
}

\section{Conceptualizando el reconocimiento de marcas de moda online: desarrollo y validación de la escala}

Online fashion

brand recognition

\author{
Muhammad Sabbir Rahman, Md Afnan Hossain, \\ Md Rifayat Islam Rushan, Mohammad Tayeenul Hoque and \\ Hasliza Hassan \\ (Author affiliations can be found at the end of the article)
}

\begin{abstract}
Purpose - This study aims to develop and validate a scale for measuring online fashion brand recognition (OFBR).

Design/methodology/approach - Given the existing literature on brand, multiple stages of studies were conducted as a part of the scale development process. The OFBR scale was validated by a step-by-step process following the scale validation methodology suggested in the specialised literature.

Findings - The results demonstrate the 25 items of five unique factors that form the OFBR construct and confirm the strong validity of the construct. This finding suggests that the five-dimensional approach (online brand familiarity, online visual simplicity, online aesthetic attraction, online brand emotion and online social reputation) plays important role to form OFBR.

Practical implications - A valid and reliable OFBR scale provides a foundation for broadening the understanding on the important constructs that form OFBR, which is essential for online fashion retailing. Knowledge of the crucial antecedents that influence consumers towards online fashion products can enhance marketers' capability to position their brands towards their target markets.
\end{abstract}

Originality/value - The relevance of this study lies in validating the scale for measuring OFBR for the first time in the literature on online fashion brand.

Keywords Brand, Scale development, Fashion, Online fashion retailing, Online brand recognition, Online fashion retail store

Paper type Research paper

(C) Muhammad Sabbir Rahman, Md Afnan Hossain, Md Rifayat Islam Rushan, Mohammad Tayeenul Hoque and Hasliza Hassan. Published in Spanish Journal of Marketing - ESIC. Published by Emerald Publishing Limited. This article is published under the Creative Commons Attribution (CC BY 4.0) licence. Anyone may reproduce, distribute, translate and create derivative works of this article (for both commercial and non-commercial purposes), subject to full attribution to the original publication and authors. The full terms of this licence may be seen at http://creativecommons.org/licences/by/4.0/ legalcode

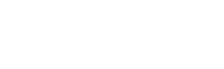




\author{
Resumen \\ Propósito - Este estudio tiene como objetivo desarrollar y validar una escala para medir el reconocimiento \\ de marcas de moda online (OFBR).
}

Metodología - Partiendo de la literatura de marca, se llevaron a cabo múltiples estudios como parte del proceso de desarrollo de la escala. La escala OFBR fue validada en un proceso de diversas etapas siguiendo la metodología de validación de escalas sugerida en la literatura especializada.

Hallazgos - Los resultados demuestran los veinticinco ítems de cinco factores únicos que forman el constructo OFBR y confirman la validez del constructo. Este hallazgo sugiere que el enfoque de cinco dimensiones (familiaridad con la marca online, simplicidad visual online, atracción estética online, emoción de la marca online y reputación social online) juega un papel importante en la formación de la OFBR.

Implicaciones prácticas - Una escala OFBR válida y fiable proporciona una base para ampliar la comprensión de los constructos importantes que forman OFBR, lo cual es esencial para la venta de moda online. Conocer los antecedentes que condicionan al consumidor al comprar productos de moda online puede mejorar la capacidad del vendedor para posicionar su marca en el mercado objetivo.

Originalidad/valor - El interés de este estudio radica en la validación de la escala para medir la OFBR por primera vez en la literatura sobre la marca de moda online.

Palabras clave Reconocimiento de marca online, Desarrollo de escalas, Moda, Venta al por menor de moda online

Tipo de trabajo Artículo de investigación

\title{
1. Introduction
}

Fashion is an activity that reflects and exposes an individual's appearance using clothing, apparel and accessories. Conceptualising fashion is composed of thoughtful and behavioural processes through which consumers present their lifestyle status to their respective society (Vieira, 2009). Fashion items are identified as a highly expressive product category that communicates the associated recognised brand preference (O'Cass, 2004). Research on fashion clothing brand has attracted considerable attention in the field of fashion marketing and literature on brand management (O'Cass and Siahtiri, 2014). Evidence suggests that consumers are comfortable with roaming in an online environment to check and purchase trendy fashion brand products (Van Deursen and Van Dijk, 2014). In recent times, the volume of clothes, footwear and other fashion-related products sold via the internet has rapidly grown as a whole worldwide (Israeli and Avery, 2017). Retailers need to adopt a different approach to remain competitive in the online market using online brand recognition (BR) tools amongst targeted online consumers. Thus, marketers should demonstrate increased intensity in fashion BR in an online environment to improve their brand identity and further attract online consumers. Recently, academicians and experts have stimulated tangible and intangible brand elements to form and extend previous theories of BR. Furthermore, they have also tested and extended various models and validated scales across industry contexts related to brand (Iglesias et al., 2019), online retail brand (Bhattacharya and Anand, 2019), fashion items (Ladhari et al., 2019; Cheung et al., 2019) and branding of fashion products (Lopez and Fan, 2009). Previous research defined online brand as "a brand that has an online presence". According to Rahman and Mannan (2018), online branding pertains to how online channels are used to support brands, which in essence are the sum of the characteristics of a product, service or organisation as perceived and experienced by a user, consumers or other stakeholders.

As explained by Keller (1993), consumers should recognise brand names when the components of a brand are visible and reflect the brand's symbolic expression through advertising. Therefore, BR by a large pool of consumers implies that the particular brand is reputable and familiar (Grewal et al., 2004; Bilgihan, 2016). The target consumers should recognise a brand to save time by reducing search costs. This notion is increasingly 
important in providing continuity and securing consumer commitment in a fast-moving online fashion brand marketplace (Hajli et al., 2017). Thus, the qualities and benefits of products must be refined and transformed in a competitive manner to communicate over an online medium and form BR in the mind of consumers, which is increasingly critical for online retail fashion brand stores (Keller et al., 2011). Selecting a prominent brand name to form recognition in the mind of consumers should be given priority as consumers purchase fashion brand products from online stores. Thus, forming an effective scale for online fashion BR (OFBR) is a strategic issue for online fashion retailers; the current study extensively contributes to this end.

Therefore, further understanding is necessary to identify the types of constructs that evoke BR in the context of online fashion retailing that can develop favourable online BR in the minds of consumers. Hence, the challenges associated with measurement are closely linked to theoretical constraints. The current study identifies two main research gaps, namely, the lack of conceptual clarity and need for a reliable and valid measurement scale to assess BR in the context of online fashion retailing. This study emphasised on formative protocol while validating scale as strongly suggested in Grace et al. (2020). First, the researchers build upon existing studies to conceptualise OFBR as a multidimensional construct (Hossain et al., 2020). Second, on the basis of this conceptualisation, we develop a formative model, given that the direction of causality is derived from items for each construct that forms OFBR (Grace et al., 2020). Third, we provide empirical testing and examine the relationship between the proposed construct of OFBR and consumers' behavioural intention (BI) in purchasing fashion products from online stores (Rahman et al., 2018).

The remainder of the article is structured as follows. We provide a critical review of the existing research on $\mathrm{BR}$ in the context of online fashion products to conceptualise constructs that are theoretically related to OFBR (i.e. antecedents and consequences). Afterwards, the study showcases a series of scale validation procedures by adopting recommendations from Churchill (1979) and Rossiter (2002). This scale development will facilitate the understanding of future research in terms of how OFBR evokes marketing efforts towards online fashion retailing to influence the behaviour of target consumers. Finally, we discuss the theoretical and managerial importance of the validated OFBR scale and give directions for future research.

\section{Literature review}

BR determines whether a brand will be embedded in consumers' consideration for current or next purchase (Chakravarti and Janiszewski, 2003). In general, consumers purchase products that they recognise at the time of purchase decision-making (Chan et al., 2016). Previous studies have focused on enhancing BR using mixed methods of traditional marketing (e.g. advertising and price promotion). However, future research should assess BR from various contexts, such as online environment (Huang and Sarigöllü, 2014). To date, scholars have measured BR using a single-item scale (Matthes et al., 2007) and also measured the brand awareness (Aaker, 1996). The present study conceptualises online BR from the context of brand names of fashion products using the five dimensions adapted from the study De Marchis et al. (2018), namely, online brand familiarity (OBF), online visual simplicity (OVS), online aesthetic attraction (OAA), online brand emotion (OBE) and online social reputation (OSR). De Marchis et al. (2018) examined cued recall (pertained to in this study as recognition) and perception towards commercial logos. In this study, we used the term cued recall with respect to the psychological aspect of the consumer under the scope of online BR. 
Consumers' decision-making for products is highly driven by the associated BR, which refers to whether consumers recognise a brand through exposure (Huang and Sarigöllü, 2014). Although brand awareness and BR have been interchangeably used in previous studies, BR with brand recall is two pivotal dimensions that illustrate brand awareness (Keller, 1993). Brand awareness pertains to the consumers' ability to recognise and recall a brand under various circumstances. Increased brand awareness drives towards achieving loyalty and long-term customer relationship opportunities for brands with consumers (Khan et al., 2015). This aspect of brand awareness consists of BR and brand recall (Aaker, 1996). Leveraging on BR and brand recall measures can be used to assess brand awareness (Walsh et al., 2008). BR is denoted as aided awareness, that is, an aided technique that enables consumers to simply remember a brand when a cue is presented (Aaker, 1992). Conversely, brand recall is defined as spontaneous awareness or the ability of consumers to retrieve a brand without mention of any product class or brand names (Aaker, 1996). Brand awareness represents a continuum of brand knowledge that ranges from the initiation of recognition of a brand name to a cognitive formation of such brand. A subtle difference is observed between brand awareness and BR (Melis et al., 2016; Rajavi et al., 2019). Similarly, BR is distinct from brand recall in terms of differences in the definitions of aided and spontaneous awareness. Therefore, measuring BR saliently and comprehensively is necessary considering its distinct difference from brand awareness and brand recall. BR is a fundamental driving force for the purchase decision-making of consumers. A prominent brand name that consumers recognise and experience will receive priority as consumers form purchase decisions. Active brand name formation is the focal point of establishing BR (Klink, 2003; Klink and Athaide, 2012). The conventional approach of measuring BR is giving consumers a set of choices with brand names and asking them to cite the brand names that they recognise. Despite the distinctiveness and ubiquitous application of BR, little attention has been given to understand the relevant and comprehensive dimensional approaches to measure BR. Thus, the present study aims to develop a multidimensional scale for measuring OFBR.

\subsection{Conceptualising the dimensions of online fashion brand recognition}

We adapted the five-dimensional approach in the conceptualisation of OFBR for three reasons. Firstly, we aim to develop the scale for BR because multidimensional scaling is one of the well-accepted and popular tools for solving a wide range of marketing problems (Bijmolt and Wedel, 1999). Particularly, BR using a multidimensional approach remains largely unexplored. Secondly, the five dimensions are conceptually consistent with BR in the context of the present study, as justified in the previous discussion. Finally, to the best of our knowledge, no research has adapted the five dimensions for understanding the role of $\mathrm{BR}$ in the context of brand names of online fashion products. Thus, we intend to further extend the validation of the five dimensions in a new context.

Brand familiarity is denoted as the required amount of time that consumers spend on processing information about a brand (Bapat, 2017), which is less for familiar brands compared with unfamiliar brands (Chen et al., 2015). Brand familiarity enables consumers to engage in message or information processing within a short period (Martin and Strong, 2016). In addition, brand familiarity retains knowledge about a brand in the consumers' memory where BR spontaneously occurs (Verhellen et al., 2016). Consumers' brand experience is also defined through brand familiarity, which consumers achieve by prior experience and exposure from the brand (Eisend and Stokburger-Sauer, 2013). In the context of the online environment, consumers want to purchase their desired products from dotcom sites because they recognise the brands through shopping experience (Rahman and 
Mannan, 2018). Several researchers have explored brand familiarity in the context of traditional retail stores and investigated its influence on shoppers' purchase intention (Park and Stoel, 2005; Ali et al., 2018). Particularly, in an online context, consumers search for Web information of familiar brands in compare to unfamiliar brands (Iglesias et al., 2011; Rahman and Mannan, 2018). In other words, well-known online brands may have an advantage from being better favoured than less familiar online brands (Ha and Perks, 2005; Park and Lennon, 2009). However, brand familiarity construct has yet to be explored in the context of the online environment and linked with online BR; the current study addresses these concerns to contribute to the marketing literature (Nepomuceno et al., 2014).

On another note, visual complexity refers to the extents of elements included in an object followed by the detailed information portrayed by that object (Deng and Poole, 2010). Visual complexity affects consumer's perception and BIs in a wide range of contexts in both online and offline contexts (Kusumasondjaja and Tjiptono, 2019). Visual complexity is associated with brand logo, which portrays the visual recognition of a brand. Despite the generic negative effect of visual complexity on consumers' processing and purchase behaviours (Khachatryan et al., 2018), consumers' BR is high when the exposure level is also high for visually complex abstracts, such as logos (Van Grinsven and Das, 2016a, 2016b). Therefore, $\mathrm{BR}$ can be enhanced through high exposure to the visual complexity of a branded logo design. Hence, BR is important in a competitive online market. In online marketplaces, sellers highlight information about their products and services directly within pictures of the products for advertising purposes. Such application enhances the visual complexity of the image and provides further information in such a manner that supports buyers' purchase judgement. However, when other sellers adopt the same strategy, the given image of products or services through an online platform will be less striking to gain recognition from the target customers. Thus, we suggest that online retailers should reduce buyers' effort by simplifying the representation of the brand and placing the product image conspicuously in the online platform to provide other viable means for catching buyers' attention and recognition towards the brand (Lee et al., 2018).

Merriam-Webster (1993) defined:

[...] aesthetics as the branch of philosophy dealing with such concept as the beautiful, the ugly, the inspiring, the comic, etc., as applicable to the fine arts, with a view to establishing the meaning and validity of critical judgments concerning works of art, and the principles underlying or justifying such judgments.

Aesthetic attraction has received significant attention from academic researchers and practitioners. A consumer evaluate the functional value of a product and consider experiential value, such as products' aesthetic attraction (Creusen et al., 2018). The appearance of a product along with perceived beauty is referred to as the aesthetic dimension of product design (Homburg et al., 2015). Aesthetic attraction plays a pivotal role when consumers do not have prior knowledge of the brand (Honea and Horsky, 2012). In an online context, web aesthetics positively expose opportunities for marketers to understand consumers behaviour and formulate strategy accordingly (Tractinsky and Lowengart, 2007). The aesthetic appeals of a product considerably enhance BR and thus stimulate the consumers' linking with the brand and brand value (Choi et al., 2016). The aesthetic attraction of the product captures consumers' attention and enhances brand appeal and recognition (Mugge et al., 2018; Crolic et al., 2019). Therefore, online BR is portrayed through the aesthetic attraction of the fashion products.

In this study, researchers denote emotionality as a brand emotion that refers to the emotional bonding between the brand and consumers. Brand emotion emerges from 
emotional branding, which is a consumer-centric, relational and story-driven approach, built through the consumers' senses and emotions (Junaid et al., 2019). Emotional experiences with a brand induce a positive effect on subsequent evaluation and reaction towards the brand (Langner et al., 2016). A positive experience creates positive emotions and satisfaction, which in turn leads to the consumers' emotional attachment to preferred brands (Grace et al., 2020). Therefore, emotion is also a crucial dimension of the brand and BR (Homburg et al., 2015). Bowden (2009) revealed that brand engagement activities, such as BR and advocacy, are outcomes of emotions or emotional involvement of a particular brand and customer. Moreover, brand emotion evokes the senses of consumers, which increases brand awareness and recognition (Kim et al., 2003). In fact, knowledge of brand emotion from the perspective of online retailing is still in its infancy (Bagdare and Jain, 2013). Previous scholars have agreed that emotion has a strong connection to online BR-related behaviours (Marken, 2003).

The social reputation of a brand refers to the overall quality as seen and judged by consumers (Dowling, 2016). Consumers seek attention through brand consumption to gain accepted in social environments and maintain social relationships (Bian and Forsythe, 2012). Consumers tend to use socially reputed and recognised brands to portray an image of prestige in social environments, which enhances consumers' self-esteem (Bhattacharya and Sen, 2003). In the context of the technology development of fashion brands through online retail platforms, sellers largely benefit by attracting consumers to interact with brands. The positive reputation of a brand can spread through social media and form the reputation of the retail stores surrounding the consumers' environment, which builds friendly attention and even affection towards brands and stimulates customers' BR for particular fashion products (Nash, 2019; Dahana et al., 2019). Therefore, BR can be explained through the social reputation of a brand.

To determine the formative or reflective construct, we carefully evaluated four rules of Jarvis et al. (2003), and according to Jarvis et al. (2003) Type II model, we have formed OFBR (formative) through five factors (i.e. OBF, OVS, OAA, OBE and OSR), (Figure 1); these five factors are reflecting by 25 items (see the section "Generating scale items").

\section{Scale development and assessment measures}

We adopted the recommendations from Churchill (1979) and Rossiter (2002) as steps for the formative measure of scale development and validation procedure of OFBR (Figure 2). We combined both processes due to their individual limitations (Diamantopoulos, 2005). The researchers skimmed and scanned the relevant literature, followed by an exploratory research method, such as focus group discussion (FGD). The exploratory research was conducted on only one group that comprises three BBA, three MBA and two EMBA students to earn partial credit in undergraduate- and graduate-level marketing management courses. The FGD included eight participants comprised of 50 per cent male and 50 per cent female, with an average age of 23.65 years. The moderators for the FGD were the researchers and a graduate research assistant with marketing research experience. The moderators provided a brief summary of BR, brand, online environment in the context of fashion brands and OFBR-related constructs. After carefully examining the FGD, the moderators manually recorded the transcripts to initially develop the items of the OFBR scale. Along with the focus group, researchers also adopted a small-scale experience survey (ES) in the form of in-depth interviews with 25 individuals (i.e. ten online consumers, five online fashion retailers, five researchers and five academic experts). The participants were selected through the researchers' requirement for eligibility in term of providing sufficient ideas and insight about online fashion brands and fashion BR. The current study adopted 


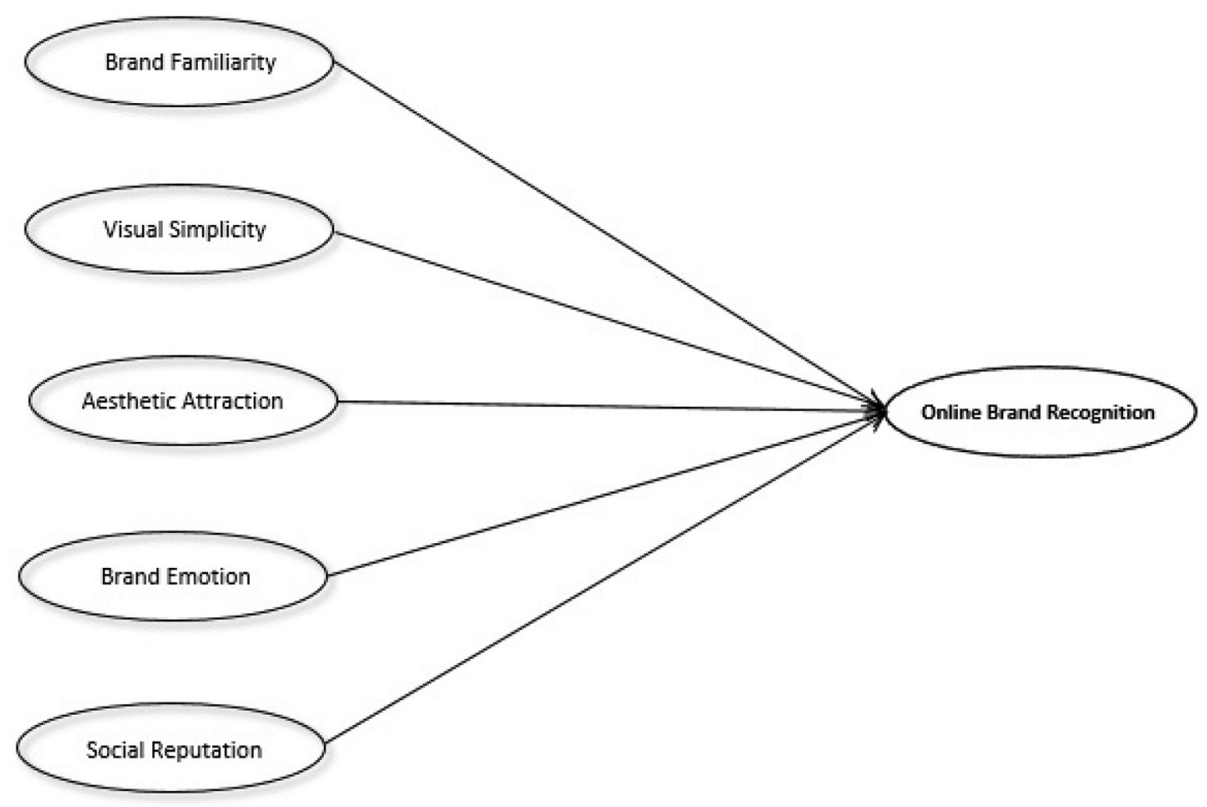

Online fashion

brand recognition

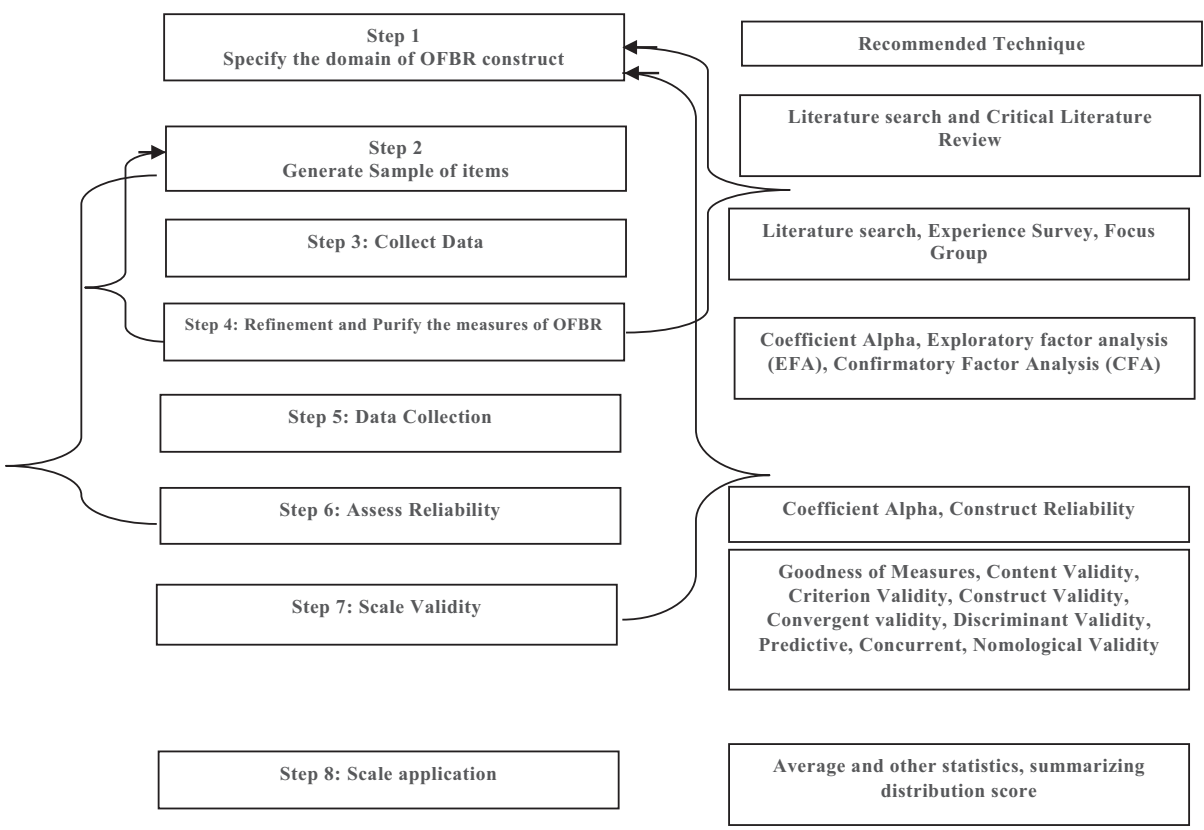

Source: Adapted from Churchill (1979) and Rossiter (2002)

Figure 2.

Steps of scale development and assessment for OFBR
OFBR formative model specifications 
such process to generate a substantial number of items under the measured constructs that may represent consumers' OFBR. The moderator used the same technique in the FGD as a discussion guide and procedure for conducting one-to-one interviews with the interviewees. As the researchers explored a considerable amount of overlap amongst the perception of the interviewees regarding OFBR (compared with the focus group), these interviews also yielded additional items that the current study incorporated to the OFBR scale. During the FGD and ES, the researchers displayed several retail outlets of online fashion products (e.g. Ajkerdeal.com, Daraz.com.bd, Bagdoom.com, PriyoShop.com, Othoba.com, Branoo.com, Shoparu.com, ShoppersBD.com, Clickbd.com and Shadmart.com), which were screened and presented through smartphones and tablets to create the stimuli and represent various types of OFBR appeal.

The researchers extended and examined the outcome of the first steps by content validity to reduce the number of items under each construct. A survey questionnaire was then administered to assess dimensionality, validity and reliability. The researchers applied exploratory factor analysis (EFA) and confirmatory factor analysis (CFA) to refine and reduce the items. In addition, $\mathrm{EFA}$ and $\mathrm{CFA}$ were also used to confirm whether the number of dimensions conceptualised can empirically verify the study object (i.e. OFBR). CFA was conducted using analysis of moment structures (AMOS 20).

\subsection{Domain definition}

To form a composite of indicators, a sound theoretical framework is required, which should clearly define the phenomenon to be measured and its subcomponents. Thus, on the basis of the above literature review, the study defines "OFBR" as cues for recalling a fashion brand in an online environment, where consumers recognise a brand because of the presence of the cues from spontaneous awareness about the online fashion brand. According to Rossiter (2002), the construction of the definition comprises a concrete object (i.e. online fashion brand) with elicited attributes (items).

\subsection{Generating scale items}

The current study explores the relevant constructs of OFBR through a critical examination of the relevant literature, where previous researchers adopted the reliability and validity of the measurement in a different context. Hence, the literature search helped us in identifying how variables (e.g. OBF, OVS, OAA, OBE and OSR) have been previously defined, and the appropriateness of selecting these dimensions has been justified. In addition, the researchers conducted the FGD (eight members) and ES with 25 participants to generate items that could offer important ideas and insights into the relevant constructs of OFBR, as derived from the extensive literature search. Researchers have identified the formation of OFBR as $\mathrm{OBF}$ (three items), OVS (three items), OAA (three items), OBE (three items) and OSR (two items), for a total of 14 items adapted from previous research. After an initial addition, another 20 items (OBF (three items), OVS (five items), OAA (four items), OBE (four items) and OSR (four items)) were generated from the outcomes of the FGD and ES methods. Therefore, a total of 34 items were initially generated. After checking and deleting double barrel, items that are redundant and ambiguous and with a total correlation of less than 0.50 were eliminated. Finally, a pool of 25 items was retained for further analysis (Table I).

\section{Methodology}

\subsection{Sampling and data collection}

This study is cross sectional in its nature, such that it involves validating the survey instrument in the context of OFBR. The population for this study comprised of individual 


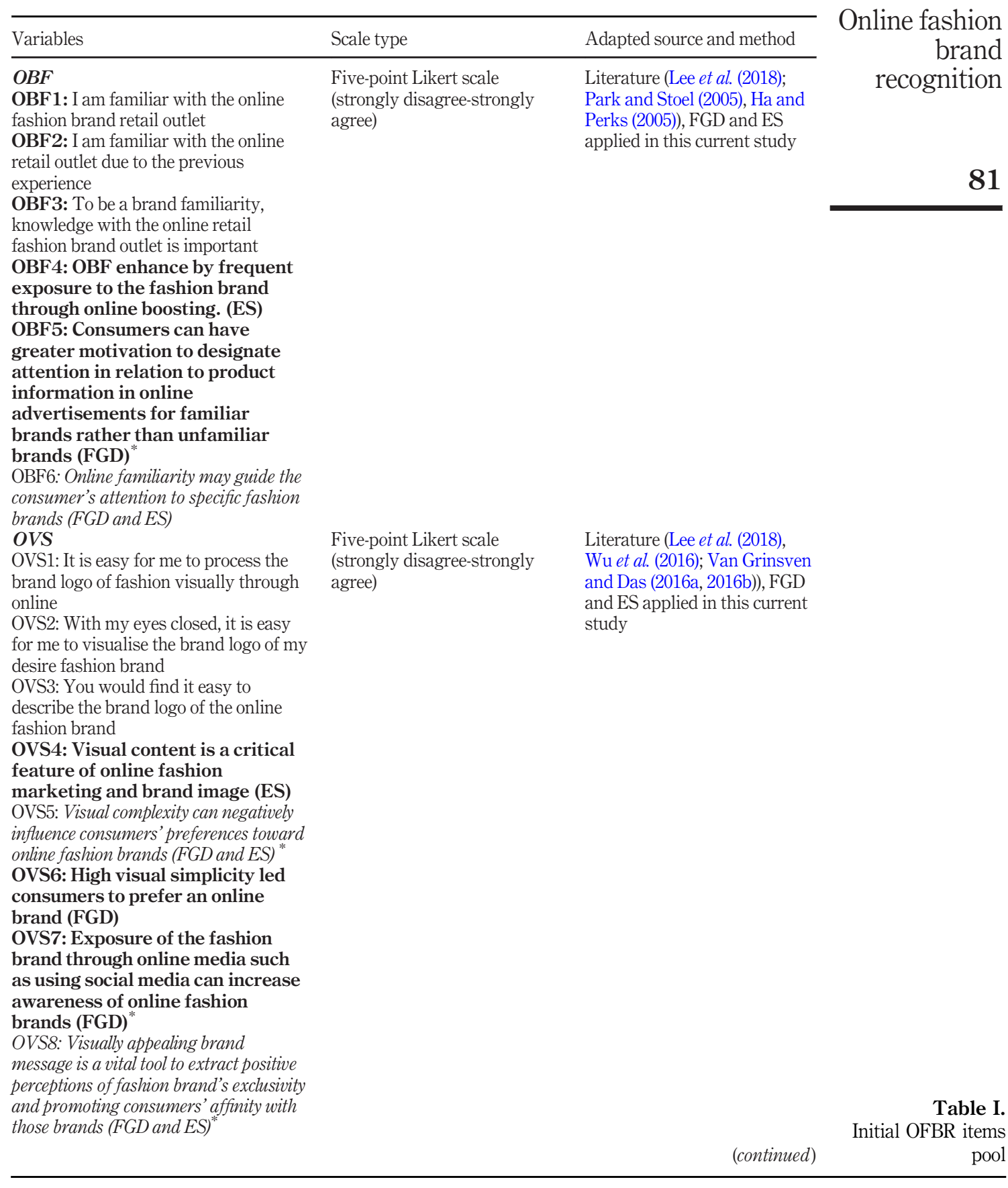




\begin{tabular}{lll}
\hline Variables & Scale type & Adapted source and method \\
\hline $\boldsymbol{O A A}$ & Five-point Likert scale & Literature (Homburg et al., \\
OAA1: The logo of the online fashion & (strongly disagree-strongly & 2015; Lavie and Tractinsky, \\
brand is visually striking & agree) & 2004), FGD and ES applied in \\
OAA2: The design of online fashion & & this current study
\end{tabular}

OAA3: Straightforwardness may serve

as a linkage between usability and aesthetics for online fashion brand OAA4: Beauty is a primary predictor of overall impression and preferences of websites regarding online fashion brand (ES)

OAA5: Aesthetic interprets of beauty is associated with delight and perception towards the online fashion brand (FGD and ES)

OAA6: Aesthetics is a strong determinant of pleasure experienced by the online user during the interaction with the relevant online fashion brand outlet (FGD)

OAA7: Visual attractiveness of the site affected users' enjoyment regarding online fashion brand (FGD and ES) *

\section{$O B E$}

OBE1: Online fashion brands gain success when their business models emphasize a collective feeling of "us" or "we", rather than you or me OBE2: Online marketers strive to create relevant and compelling content, through "joint creation of value by the company and the customer" OBE3: The online fashion brand is my first choice when I buy related fashion products

OBE4: My love for the fashion brand is incomparable to the other online fashion brand (ES)* OBE5: Online marketers allow experiencing the fashion brand more profoundly and having an emotional connection with it at a deeper level (FGD and ES)

OBE6: Online fashion brand stimulate consumers' imagination and involving them emotionally (FGD)*

Five-point Likert scale (strongly disagree-strongly agree)
Literature (Marken (2003), Kim et al. (2003); Ding and Tseng (2015)), FGD and ES applied in this current study

Table I. 


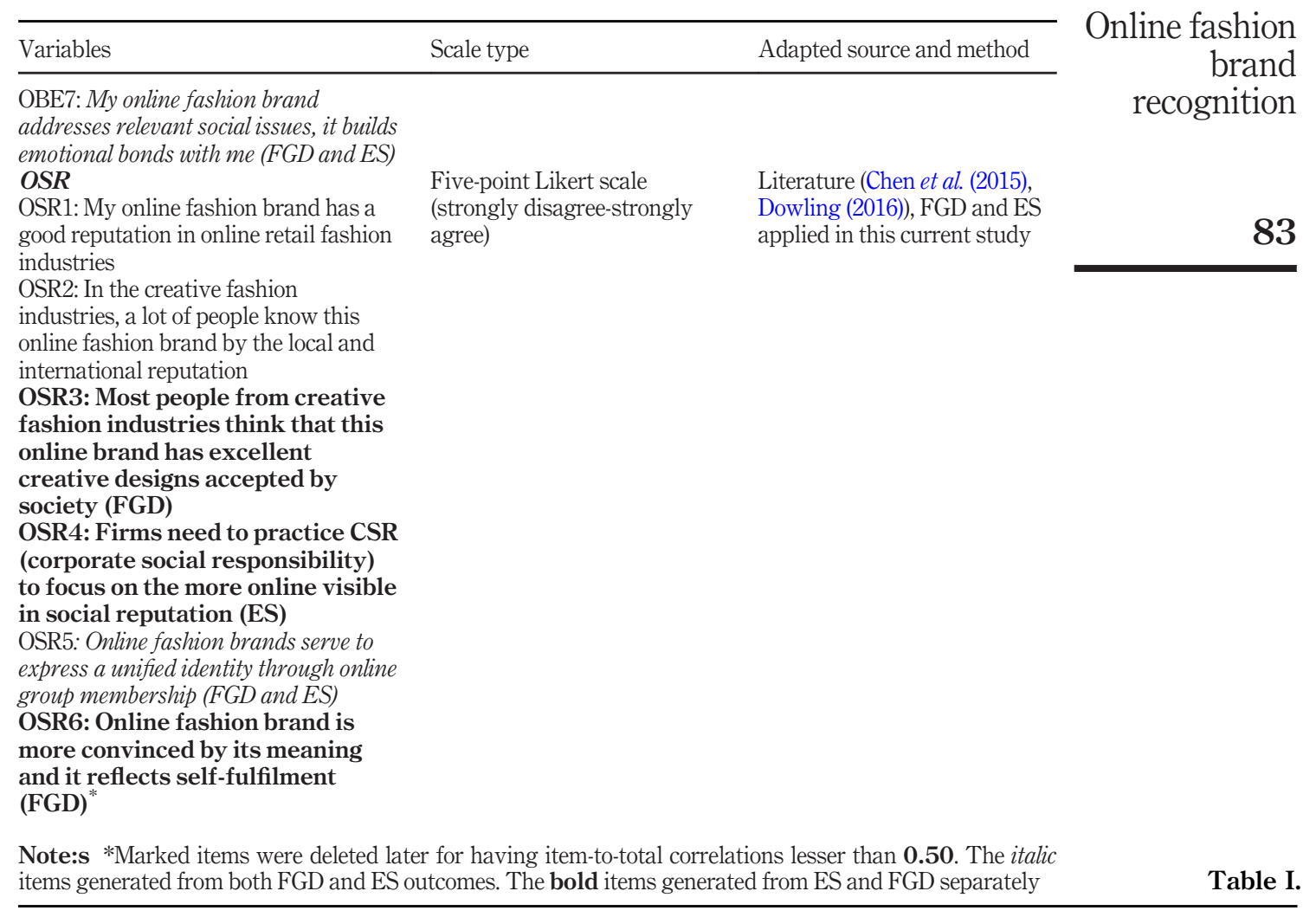

men and women who have purchased or intend to purchase fashion products from online fashion retail stores. The researchers applied the convenience sampling method, which was operationalised in two major metropolitan areas, namely, Dhaka and Chittagong, via the mall intercept method. In Bangladesh, major online retail stores are operating in these two cities, and consumers living in these cities tend to be conscious of purchasing online fashion brands and of their purchasing power. The respondents were limited to consumers who purchased any fashion brand items from online within the previous six months because this study is focused on fashion products only. Data were collected from survey questionnaires from October 2018 to January 2019. Amongst the 300 survey questionnaires distributed, 230 were finally analysed after excluding questionnaires with missing responses. The survey instrument comprised of 25 items, and the researchers verified the reliability and validity of the measures of the OFBR constructs. In total, 60 per cent of the participants were female, and 40 per cent were male. Amongst them, 60 per cent were working, 20 per cent were housewives and 20 per cent students. As a whole, the majority of the respondents have bought online apparel products ( 40 per cent), whereas 60 per cent bought other categories of fashion products (e.g. bags, wristwatches, bracelets, stylish home and living materials and footwear). Afterwards, the subjects indicated how much they perceived OFBR, which was listed using the 25 items on a five-point Likert scale that ranged from $1=$ strongly disagree to $5=$ strongly agree. 
SJME

24,1

To avoid the common method variance of the measurement constructs, the researchers applied procedural and statistical tests for control common method bias (variance). The researchers define common method variance as that which is attributable to the measurement rather than to the construct of interest. Variance can influence the results due to response biases, such as halo effects, social desirability, acquiescence, leniency effects or yes and no answers (Spector, 1994; Podsakoff et al., 2003).

Therefore, the study collected data through face-to-face surveys and a question randomisation option for each respondent in a shuffled approach. In addition, the researchers carefully constructed the items to avoid ambiguous or unfamiliar terms and vague concepts; when such concepts were used, the respondents were provided with examples; the questions were presented in a simple, specific and concise manner, double-barrelled questions and complicated syntax were avoided (Tourangeau et al., 2000). In terms of the statistical measure to control for common method variance, the researchers tested Harman's single-factor test with an unrotated factor solution through EFA using SPSS. The result indicates an explained variance of 23.6 per cent, which is relatively less than the threshold of 50 per cent as suggested by Podsakoff $e$ t al. (2003). The current research adopted the structural equation modelling (SEM) approach using AMOS because this method can provide the best solution for multidimensionality with regard to scale development (Farooq, 2016). In addition, SEM can be useful for measuring the psychometric properties of a scale or construct (Babin and Svensson (2012). The researchers also used Harman's single-factor test through CFA using AMOS for further analysis. The method bias was not substantial because the hypothesised model poorly fits the data within a single-factor model (goodness-of-fit index $(\mathrm{GFI})=0.70$; adjusted GFI $(\mathrm{AGFI})=0.67$; normed fit index $(\mathrm{NFI})=0.65$; IFI = 0.69; Tucker-Lewis index $(\mathrm{TLI})=0.66$; root mean square residual $(\mathrm{RMR})=0.10$; root mean squared error of approximation (RMSEA) $=0.13$ ). In summary, the findings confirm the nonexistence of common method variance in the data set (Malhotra et al., 2006).

\subsection{Item refinement and purification}

This step is essential for improving the scale because it identifies the ineffective items under each construct to avoid confusion. The researchers applied the item-to-total correlation matrix test for the items and verified the Cronbach's $\alpha$ values of each construct. At this stage, a total of 230 filled questionnaires were administered. The questionnaire contained 25 OFBR items, which were rated using a Likert scale that ranges from 1 (strongly disagree) to 5 (strongly agree). Each respondent was requested to fill the survey questionnaire regarding their preferred online fashion product brand. Table II presents the results in relation to the item-to-total correlation values for each construct and corresponding coefficient $\alpha$ values. In addition, the findings indicate that the item-to-total correlation values for all items reached more than 0.70 . Items with item-to-total correlation values of $<0.50$ were omitted. All Cronbach's $\alpha$ values were above 0.70 , which indicated strong internal consistency of the data. Therefore, the research retained 25 items for further analyses (Table II).

\subsection{Exploring the dimensional structure of online fashion brand recognition}

After refining and purifying the scale items, the researchers applied EFA to the data set to verify whether the five OFBR items are uniquely be explored. The researchers applied an orthogonal rotation of Varimax to evaluate the meaningful interpretation of the structure of the factors as generated from the data. We extracted a five-factor solution, with each one having an eigenvalue above 1 and explain 70.79 per cent of the total variance. The KaiserMeyer-Olkin measure of sampling adequacy was 0.881 , which indicates a commendable level, as suggested by Kaiser and Rice (1974). Bartlett's test for sphericity was significant $\left(X^{2}=3,757.242, p<0.00\right)$. The researchers labelled the five new empirically derived factors 


\begin{tabular}{|c|c|c|c|c|c|c|}
\hline Construct/items & Standardised loading* & $\mathrm{CR}$ & AVE & $\begin{array}{l}\text { Item-total } \\
\text { correlations }\end{array}$ & $\begin{array}{c}\text { Coefficient } \\
\alpha\end{array}$ & \multirow{2}{*}{$\begin{array}{l}\text { Unline tashion } \\
\text { brand } \\
\text { recognition }\end{array}$} \\
\hline \multicolumn{2}{|l|}{$\mathrm{OBF}$} & \multirow[t]{6}{*}{0.91} & \multicolumn{2}{|l|}{0.67} & \multirow[t]{6}{*}{0.79} & \\
\hline OBF1 & 0.74 & & & 0.78 & & \multirow{5}{*}{85} \\
\hline OBF2 & 0.81 & & & 0.76 & & \\
\hline OBF3 & 0.88 & & & 0.74 & & \\
\hline OBF4 & 0.79 & & & 0.79 & & \\
\hline OBF6 & 0.87 & & & 0.81 & & \\
\hline OVS & & \multirow[t]{6}{*}{0.90} & \multirow[t]{6}{*}{0.64} & & \multirow[t]{6}{*}{0.77} & \\
\hline OVS1 & 0.78 & & & 0.78 & & \\
\hline OVS2 & 0.84 & & & 0.79 & & \\
\hline OVS3 & 0.83 & & & 0.74 & & \\
\hline OVS4 & 0.79 & & & 0.84 & & \\
\hline OVS6 & 0.77 & & & 0.75 & & \\
\hline OAA & & \multirow[t]{6}{*}{0.90} & \multirow[t]{6}{*}{0.66} & & \multirow[t]{6}{*}{0.79} & \\
\hline OAA1 & 0.81 & & & 0.76 & & \\
\hline OAA2 & 0.80 & & & 0.74 & & \\
\hline OAA3 & 0.79 & & & 0.79 & & \\
\hline OAA4 & 0.85 & & & 0.81 & & \\
\hline OAA6 & 0.83 & & & 0.84 & & \\
\hline OBE & & \multirow{6}{*}{0.90} & \multirow{6}{*}{0.66} & & \multirow{6}{*}{0.80} & \\
\hline OBE1 & 0.82 & & & 0.75 & & \\
\hline OBE2 & 0.84 & & & 0.82 & & \\
\hline OBE3 & 0.79 & & & 0.81 & & \\
\hline OBE5 & 0.76 & & & 0.85 & & \\
\hline OBE7 & 0.85 & & & 0.75 & & \\
\hline OSR & & \multirow[t]{6}{*}{0.92} & \multirow[t]{6}{*}{0.70} & & \multirow[t]{6}{*}{0.76} & \\
\hline OSR1 & 0.79 & & & 0.72 & & \\
\hline OSR2 & 0.77 & & & 0.76 & & \\
\hline OSR3 & 0.86 & & & 0.78 & & \\
\hline OSR4 & 0.88 & & & 0.71 & & \\
\hline OSR5 & 0.89 & & & 0.72 & & \\
\hline \multicolumn{6}{|c|}{$\begin{array}{l}\text { Notes: AVE, average variance extracted; OBF: online brand familiarity, OVS: online visual simplicity, } \\
\text { OAA: online aesthetic attraction, OBE: online brand emotion and OSR: online social reputation. *All } \\
\text { parameter estimates are significant at the } 0.001 \text { level }\end{array}$} & $\begin{array}{r}\text { Table II. } \\
\text { Results of item } \\
\text { purification and CFA }\end{array}$ \\
\hline
\end{tabular}

as follows: OBF, OVS, OAA, OBE and OSR. All items under each construct provided factor loadings of more than 0.70, which is satisfactory as per Hair et al. (2009).

The following study explained the approach taken by the researchers to conduct and assess the validity of OFBR using CFA, whereas the current study applied Anderson and Gerbing's (1991) recommendation in conducting CFA (Table II) to establish the construct reliability and discriminant validity of the multi-item scales proposed. We constructed an SEM using AMOS to assess the relationships amongst underlying constructs. To test our model, we used chisquare value, which was significant. Moreover, the current study used several indexes to verify the overall fit of the model, GFI, TLI, AGFI, CFI, SRMR and RMSEA (Bagozzi and Yi, 1988). The result from CFA analysis also confirms that the composite reliability (CR) and average variance extracted (AVE) values were satisfactorily high for all latent factors (Table II).

\subsection{Validity assessment (content (construct: convergent and discriminant)}

Previous scholars have defined content validity as the extent to which the items of constructs or instrument covers the meanings of the concept that is being studied for a 
SJME

24,1

86

particular research (Creswell and Creswell, 2017). Content validity aims to clarify the scope of a concept (i.e. OFBR) and determine whether the measure sufficiently reflects the domain of the concept (Bollen, 1989). It comprises the theoretical definition of constructs and a wellstructured literature review (Gomez et al., 2005). Building on the cited logic, the researchers confirmed the content validity of the measured items, which reflect the justified dimensions of BR from the perspective of online fashion.

In addition, the term construct validity is related to the degree to which the test items measure the constructs (i.e. OBF, OVS, OAA, OBE and OSR), which they were designed to measure. We assessed the construct validity of the scores obtained from an instrument by applying factor analytic techniques (Sun, 2005). According to Campbell and Fiske (1959), construct validity can be assessed using two approaches, namely, convergent and discriminant validity. The authors defined convergent validity as the degree to which multiple attempts to measure the same concept when two or more measures of the same concept should correlate highly if they are valid measures of the concept. Thus, the researchers tested the coefficients of CR and AVE for convergent validity. CR was used to assess the internal consistency of the measurement model. The results reflect that all constructs had high values of $\mathrm{CR}$, which ranged above the benchmark of 0.6 , as recommended by Bagozzi and $\mathrm{Yi}$ (1988). The results also suggest the high internal reliability of the data set. In addition, AVE values indicate the percentage of the variance of the construct by sampling an individual item. All constructs show high AVE values above the benchmark of 0.5, as recommended by Fornell and Larcker (1981) (Table II). In summary, the items adequately explained the variance of each construct. In addition, the EFA analysis results indicate that all five factors displayed unidimensionality, such that each set of items represents the intended concept and loaded on only one construct. Thus, the analysis provided evidence of sufficient convergent validity. According to Campbell and Fiske (1959), discriminant validity refers to the extent to which measures of the constructs (i.e. OBF, OVS, $\mathrm{OAA}, \mathrm{OBE}$ and OSR) are relatively distinct, and their correlation values are not an absolute value of 0 nor 1 . Similar constructs will produce high correlation values and indicate substantial collinearity between constructs, whereas unrelated constructs will result in low correlation values and demonstrate that the constructs are distinct from one another (Hair et al., 2009).

The current study conducted correlation analysis on the five factors of OFBR. The results highlight that all constructs are not highly correlated with one another because their coefficients are less than 0.70 (Tables III and IV). This finding implies that the constructs are unique and unrelated to one another, which in turn indicates discriminant validity. In conclusion, the statistical results indicated that the test of the measurement model, such as content and convergent and discriminant validity measures was satisfactory.

\begin{tabular}{lccccc}
\hline Variables & 1 & 2 & 3 & 4 & 5 \\
\hline OBF & 0.81 & & & & \\
OVS & $0.64^{* *}$ & 0.80 & & & \\
OAA & $0.62^{* *}$ & $0.65^{* *}$ & 0.81 & & \\
OBE & $0.58^{* *}$ & $0.59^{* *}$ & $0.57^{* *}$ & 0.82 & 0.83 \\
OSR & $0.63^{* *}$ & $0.61^{* *}$ & $0.67^{* *}$ & $0.62^{* *}$ &
\end{tabular}

Table III. analysis of five factors and model fit indexes $(N=230)$
Notes: The square root of the AVE of each construct is bold and shown in the diagonal. $N=230$; All Pearson correlations are generated from the composited constructs. The square root of the AVE of each construct is shown in the diagonal. **Correlation is significant at the $p<0.01$ level (two-tailed) 


\subsection{Confirming the dimensional structure of online fashion brand recognition}

The study used SEM and conducted a set of CFAs corresponding to the three models (shown in Tables III and IV) to examine the relation of the scale items to the OFBR construct. In this step, we aim to validate the second-order structure of OFBR by adopting the recommendation of Thomson et al. (2005). The study assessed the relationship between the scale items and the OFBR construct using CFA corresponding to three consecutive models. Model 1 assumes that all 25 items load directly onto a single latent OFBR construct. Model 2 assumes five equally weighted first-order latent factors, labelled OBF, OVS, OAA, OBE and OSR, form second-order factor (OFBR) with no correlations permitted among the first-order latent factors. Model 3 is similar to Model 2, except that the first-order factors that modelled as correlated. This model aims to test the notion that the five dimensions (OBF, OVS, OAA, OBE and OSR) can be conceptualised as interrelated first-order factors loading onto a global OFBR latent construct. The results from CFA analysis explore that all three models show that each path is positive and significant, suggesting that each indicator contributes to the OFBR construct directly (Model 1) or to the first-order factors (OBF, OVS, OAA, OBE and OSR), which are themselves significantly tied to OFBR (Models 2 and 3). The study evaluates the fit indexes of each model to examine which model best fits the data. Besides, a CMINDF (minimum discrepancy divided by the degrees of freedom) statistic of less than 5 is considered adequate, with lower values being meritorious. For NFI, RFI and CFI statistics, higher values are expected, which is $>0.90$. According to these criteria, any of the three models is satisfactory and acceptable, because each possesses CMINDF statistics below 5 and NFI, RFI (relative fit index), and CFI (comparative fit index) statistics above 0.90 (Tables III and IV). However, the $\chi^{2}$ statistics used to enhance the comparison of the models that suggest Model 2 reflects significantly better fit $\left(\chi^{2}=105.10\right)$ compared with Models 1 $\left(\chi^{2}=365.47\right)$ and $3\left(\chi^{2}=219.78\right)$. Thus, the study confirmed that Model 2 holds that OBF, OVS, OAA, OBE and OSR (five factors) that form the OFBR construct. Therefore, the researchers also confirm that the OFBR construct is formative via five dimensions.

\subsection{Predictive, concurrent and nomological validity}

The final stage of the scale development of OFBR examines the predictive and concurrent validity of the new construct. According to Sekaran and Bougie (2011), predictive validity refers to the extent to which the measures can predict a future criterion, which is theoretically justified. Therefore, the researchers used SEM to examine the relationships amongst the proposed related constructs of OFBR. This step aims to examine the predictive and concurrent validity of OFBR. Many scholars have examined and proved that consumers' online BR with regard to fashion products has a substantial influence on their BI towards purchasing from online stores (Kawaf and Istanbulluoglu, 2019).

The current study measured BI towards purchasing from online stores to test predictive validity. The researchers adapted five items for BI from Hahn and Kim (2009) and

\begin{tabular}{lcccccc}
\hline Model of contrast & CMIN & DF & CMIN/DF & NFI & RFI & CFI \\
\hline Model 1 & 365.47 & 89 & 4.106 & 0.91 & 0.89 & 0.95 \\
Model 2 & 105.10 & 58 & 1.812 & 0.94 & 0.91 & 0.97 \\
Model 3 & 219.78 & 72 & 3.052 & 0.93 & 0.90 & 0.96
\end{tabular}

Notes: CMIN/DF (minimum discrepancy divided by the degrees of freedom); NFI (normed fit index), RFI (relative fit index) and CFI (comparative fit index) statistics above 0.90

Table IV. CFAs comparing three models of $\operatorname{OFBR}(N=230)$ 
SJME

24,1

88

Zhang and Kim (2013). A five-point Likert scale ranging from 1 (strongly disagree) to 5 (strongly agree) was used to measure the constructs. The results of SEM analysis proved that a significant relationship exists between OFBR and BI towards purchasing from online stores $(\beta$ (estimate) $=0.671$, critical ratio $=4.785, p<0.000)$. Thus, the significant relationship between OFBR and BI towards purchasing from online stores supported the predictive validity of the scale.

The result from the fit indexes also suggest that the proposed construct is well defined and confirmed that online fashion brands are indeed a multidimensional construct. Figure 3 illustrates the standardised regression coefficients for the five factors, which constitute the online fashion brand scale. The result of the standardised regression confirmed nomological validity, which assesses the degree of the constructs as expected. All hypothesised directions support the nomological validity of the proposed construct.

\section{Discussion and conclusion}

Evidence from exploratory and empirical analyses suggests that the OFBR constructs are multidimensional as indicated by good fit and the five-factor model. Furthermore, the results of EFA and CFA maintained and justified the five unipolar categories (i.e. OBF, OVS, OAA, OBE and OSR). In addition, the findings embody consumers' fashion BR in the online environment. The researchers supported the evidence through extensive reliability and validity testing to reach the norms suggested by previous researchers.

The results suggested that consumers are highly sensitive to online fashion products in terms of familiarity and visual simplicity of the presentation of brands in the online environment. Consumers also provide significant weights on OBE, OSR and OAA in response to OFBR. These results are consistent with findings of researchers, that is, the coexistence of positive and negative feelings (Luan et al., 2019; Hanson et al., 2019). Further research is examined the effects of OFBR on BI.

\section{Theoretical implications}

This research contributes to prior literature such as Badura and Foltán (2010); Van Grinsven and Das (2016a, 2016b) and Washburn and Plank (2002) by providing a holistic scale that demonstrates the construction of OFBR scale. Our empirical study reports the relative importance of OFBR. It shows that all five constructs (OBF, OVS, OAA, OBE and OSR) should be holistically taken into account when measuring OFBR. Brands with higher levels of familiarity have higher levels of liking among both consumers and retail managers. In other words, well-known fashion brands may have an advantage from being better liked

Figure 3.

Structural equation model of OFBR towards buying intention

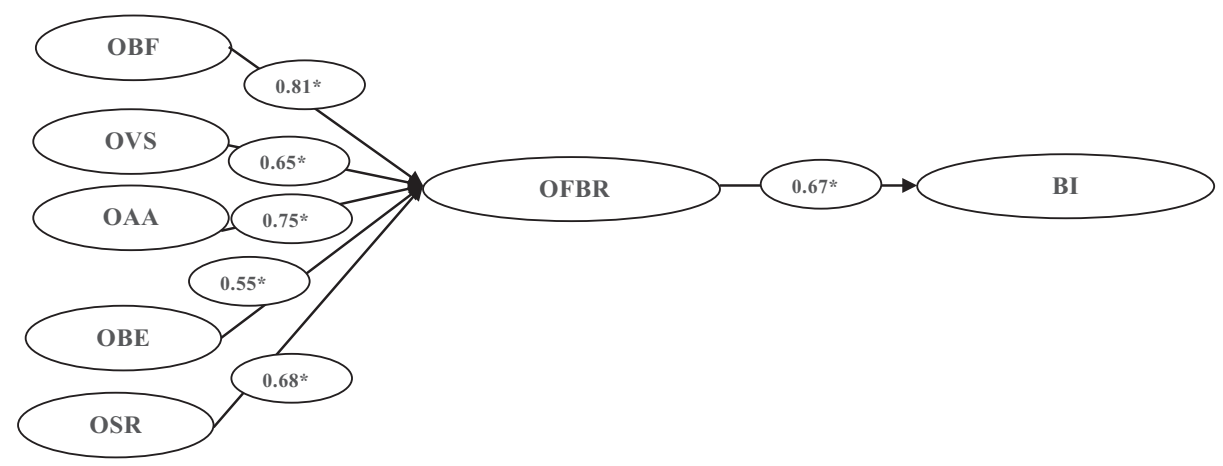


than less familiar fashion brands (Colombo and Morrison, 1989; Laroche et al., 1996). In a similar vein, the online familiarity of a particular brand guide consumer attention to specific brands and develops confidence towards that brand to form an intention to purchase that fashion brand, which is also positively related to consumers' actual behaviour toward the fashion brand (Woodside and Wilson, 1985).

The implications of this study are significant for scholars in the field of online retail marketing. As the number of internet users continues to increase, the opportunities for online shopping brand continue to expand as well. Previous researchers have conceptualised quality and prices as the most essential elements for consumers (Bolton and Drew, 1991). However, recently, the situation has become complex, especially in the online retail environment, where consumers prefer a brand by considering multidimensional values, such as utilitarian and hedonic values (Grewal et al., 2003). We define utilitarian value as the overall judgement of a brand based on functional benefits and sacrifices. Thus, this value is relevant for a task-specific use of online shopping. For example, consumers shop online because of the convenience of locating and comparing quality merchants and evaluating price/quality ratios through recognition of online brands (Mathwick et al., 2001).

Conversely, the hedonic value is defined as the overall judgement of experienced benefits and sacrifices, such as entertainment and escapism. For example, consumers frequently shop online out of the appreciation of the experience rather than simply for task completion. On the basis of the two theories (i.e. utilitarian and hedonic values), the current research contributes to the existing literature on online fashion branding by empirically validating the OFBR scale, which can be used to measure the degree of consumers' recognition of online fashion brands. The OFBR scale validated in this work is the first scale of its type, which captures the concept of the online fashion brand retail sector, which has been ignored by existing studies on brand love, relationship between consumers and brands, attachment, involvement and loyalty scales (Batra et al., 2012; Hollebeek et al., 2014).

\section{Managerial implications}

The current study suggests that online fashion retailers should capitalise on the power of online BR, which shoppers use as internal information before making purchase decisions on the internet. Fashion brands that are recognised in an online environment and positively perceived by target consumers are more likely to be objects of purchase behaviour. Thus, local and international online fashion brand retailers can benefit from building OFBR using OBF, OVS, OAA, OBE and OSR to enhance the purchase behaviours of target consumers. The medium for online selling of fashion brands appears to be a strong potential marketing and distribution strategy for retailers with established online BR.

The findings also benefit the retail managers of online fashion brands who intend to develop a strong brand amongst target customers by applying the validated OFBR scale, which can significantly predict the consequences of online purchase behaviour of a fashion brand. The research outcome can assist brand managers in robustly understanding the nature of consumer perception in the formation of $\mathrm{BR}$, which can improve the management of online fashion brands.

An information quality regarding $\mathrm{OBF}$, OVS in representing the brand, OAA, OBE and OSR may provide customers with easy-to-read brand-related information or enable them to compare information with other fashion brands, which is essential for OFBR. The findings suggest that online fashion brand retailers should communicate their brand aggressively to optimise their respective BR. Domestic and international online fashion retailers should emphasise their fashion brand through all available media in online channels to compete in this industry. Park and Stoel (2005) revealed that consumers who recognise online apparel 
retailer brands are less likely to perceive risks and more likely to purchase from said fashion retailers. Therefore, using the pre-attained brand image and recognition will assist online fashion brand retailers in attracting more online shoppers. In addition, the dimensions of the validated OFBR scale may provide online fashion brand marketers with primitive strategic parameters to stimulate meaningful towards online brand experiences. Managers can gain knowledge of existing scores for OFBR amongst target customers and across dimensions by adopting the proposed scale. Above all, the proposed online fashion BR scale will be particularly useful for brand managers in international fashion clothing who want to grow a foothold in the fashion industry. Local and international fashion brands are offering foreign brands and aim to operate in other regions, such as Bangladesh, to satisfy the appetite for international clothing brands amongst local consumers. To capitalise on these advantages to the fullest, marketers for online fashion brands should understand the online BR of consumers. Thus, developing the OFBR scale is a significant step forward in this strategic direction.

\section{Limitation and future research}

This study comes with specific limitations and suggestions for future research. The major limitation is the reliance on non-probabilistic methods of sampling, which may not be representative of online consumers. The study is cross sectional and exploratory in nature. Therefore, further research is recommended for assessing the generalisability of categories of OFBR as found in this study across other product/service-specific samples. Moreover, the BR scale has been validated in only one country (Bangladesh) and only in the context of fashion brands. To render the model more generalisable, it should be tested across nations and other products/services. Furthermore, future research may focus on including additional online shopping dimensions that construct online shopping behaviour along with BR. For example, future research may investigate online brand interactivity, online brand devotion, customers' online value creation and e-sensory aspects of shopping. Hence, validating the OFBR scale will lay a concrete foundation for the validation of other comprehensive scales of online fashion brands for future endeavours.

\section{References}

Aaker, D. (1992), "Managing the most important asset: brand equity", Planning Review, Vol. 20 No. 5, pp. $56-68$.

Aaker, D.A. (1996), "Measuring brand equity across products and markets", California Management Review, Vol. 38 No. 3, pp. 102-120.

Ali, A., Tarofder, A.K. and Azam, S.F. (2018), "Neuroticism indifference to brand familiarity and social influence towards purchase intention in social networking services (SNS) in Malaysia", Asian Journal of Marketing, Vol. 12 No. 1, pp. 1-11.

Anderson, J.C. and Gerbing, D.W. (1991), "Predicting the performance of measures in a confirmatory factor analysis with a pretest assessment of their substantive validities", Journal of Applied Psychology, Vol. 76 No. 5, pp. 732-740.

Babin, B.J. and Svensson, G. (2012), "Structural equation modeling in social science research: issues of validity and reliability in the research process", European Business Review, Vol. 24 No. 4, pp. 320-330.

Badura, Š. and Foltán, S. (2010), "Advanced scale-space, invariant, low detailed feature recognition from images-car brand recognition”, Proceedings of the International Multiconference on Computer Science and Information Technology, IEEE, pp. 19-23. 
Bagdare, S. and Jain, R. (2013), "Measuring retail customer experience”, International Journal of Retail and Distribution Management, Vol. 41 No. 10, pp. 790-804.

Bagozzi, R.P. and Yi, Y. (1988), "On the evaluation of structural equation models", Journal of the Academy of Marketing Science, Vol. 16 No. 1, pp. 74-94.

Bapat, D. (2017), "Impact of brand familiarity on brands experience dimensions for financial services brands", International Journal of Bank Marketing, Vol. 35 No. 4, pp. 637-648.

Batra, R., Ahuvia, A. and Bagozzi, R.P. (2012), "Brand love", Journal of Marketing, Vol. 76 No. 2, pp. 1-16.

Bhattacharya, C.B. and Sen, S. (2003), "Consumer-company identification: a framework for understanding consumers' relationships with companies", Journal of Marketing, Vol. 67 No. 2, pp. 76-88.

Bhattacharya, S. and Anand, V. (2019), "What makes the Indian youths to engage with online retail brands: an empirical study", Global Business Review, pp. 1-23.

Bian, Q. and Forsythe, S. (2012), "Purchase intention for luxury brands: a cross cultural comparison", Journal of Business Research, Vol. 65 No. 10, pp. 1443-1451.

Bijmolt, T.H. and Wedel, M. (1999), "A comparison of multidimensional scaling methods for perceptual mapping”, Journal of Marketing Research, Vol. 36 No. 2, pp. 277-285.

Bilgihan, A. (2016), "Gen Y customer loyalty in online shopping: an integrated model of trust, user experience and branding", Computers in Human Behavior, Vol. 61, pp. 103-113.

Bollen, K.A. (1989), Structural Equations with Latent Variables, John, New York, NY.

Bolton, R.N. and Drew, J.H. (1991), "A multistage model of customers' assessments of service quality and value", Journal of Consumer Research, Vol. 17 No. 4, pp. 375-384.

Bowden, J. (2009), "Customer engagement: a framework for assessing customer-brand relationships: the case of the restaurant industry", Journal of Hospitality Marketing and Management, Vol. 18 No. 6, pp. 574-596.

Campbell, D.T. and Fiske, D.W. (1959), "Convergent and discriminant validation by the multitraitmultimethod matrix", Psychological Bulletin, Vol. 56 No. 2, pp. 81-105.

Chakravarti, A. and Janiszewski, C. (2003), "The influence of macro-level motives on consideration set composition in novel purchase situations", Journal of Consumer Research, Vol. 30 No. 2, pp. 244-258.

Chan, F.F.Y., Lowe, B. and Petrovici, D. (2016), "Processing of product placements and brand persuasiveness", Marketing Intelligence and Planning, Vol. 34 No. 3, pp. 355-375.

Chen, M.H., Chang, Y.Y. and Lo, Y.H. (2015), "Creativity cognitive style, conflict, and career success for creative entrepreneurs", Journal of Business Research, Vol. 68 No. 4, pp. 906-910.

Cheung, J., Vazquez, D. and Conway, T. (2019), "Personalised and participative branding through fashion blogging", Social Commerce, Palgrave Macmillan, Cham, pp. 59-81.

Choi, E., Ko, E. and Kim, A.J. (2016), "Explaining and predicting purchase intentions following luxuryfashion brand value co-creation encounters", Journal of Business Research, Vol. 69 No. 12, pp. $5827-5832$.

Churchill, G.A. Jr (1979), “A paradigm for developing better measures of marketing constructs”, Journal of Marketing Research, Vol. 16 No. 1, pp. 64-73.

Colombo, R.A. and Morrison, D.G. (1989), "Consumer preference formation and pioneering advantage", Journal of Marketing Research, Vol. 26 No. 3, pp. 285-298.

Creswell, J.W. and Creswell, J.D. (2017), Research Design: Qualitative, Quantitative, and Mixed Methods Approaches, Sage publications.

Creusen, M.E., Gemser, G. and Candi, M. (2018), “The influence of experiential augmentation on product evaluation”, European Journal of Marketing, Vol. 52 Nos No. 5/6, pp. 925-945.
Online fashion

brand

recognition 
Crolic, C., Zheng, Y., Hoegg, J. and Alba, J.W. (2019), “The influence of product aesthetics on consumer inference making", Journal of the Association for Consumer Research, Vol. 4 No. 4, pp. 398-408.

Dahana, W.D., Miwa, Y. and Morisada, M. (2019), "Linking lifestyle to customer lifetime value: an exploratory study in an online fashion retail market", Journal of Business Research, Vol. 99, pp. 319-331.

De Marchis, G.P., Reales-Avilés, J.M. and Rivero, M.D.P. (2018), "Comparative values of variables related to brand logos", Measuring Business Excellence, Vol. 22 No. 1, pp. 75-87.

Deng, L. and Poole, M.S. (2010), "Affect in web interfaces: a study of the impacts of web page visual complexity and order”, MIS Quarterly, Vol. 34 No. 4, pp.711-730.

Diamantopoulos, A. (2005), "The C-OAR-SE procedure for scale development in marketing: a comment", International Journal of Research in Marketing, Vol. 22 No. 1, pp. 1-9.

Ding, C.G. and Tseng, T.H. (2015), "On the relationships among brand experience, hedonic emotions, and brand equity", European Journal of Marketing, Vol. 49 No. 7/8, pp. 994-1015.

Dowling, G. (2016), "Defining and measuring corporate social reputations", Annals in Social Responsibility, Vol. 2 No. 1, pp. 18-28.

Eisend, M. and Stokburger-Sauer, N.E. (2013), "Brand personality: a meta-analytic review of antecedents and consequences", Marketing Letters, Vol. 24 No. 3, pp. 205-216.

Farooq, R. (2016), "Role of structural equation modeling in scale development", Journal of Advances in Management Research, Vol. 13 No. 1, pp. 75-91.

Fornell, C. and Larcker, D.F. (1981), Structural Equation Models with Unobservable Variables and Measurement Error: Algebra and Statistics, The University of MI.

Gomez, R., Burns, G.L., Walsh, J.A. and Hafetz, N. (2005), “A multitrait-multisource confirmatory factor analytic approach to the construct validity of $\mathrm{ADHD}$ and $\mathrm{ODD}$ rating scales with Malaysian children”, Journal of Abnormal Child Psychology, Vol. 33 No. 2, pp. 241-254.

Grace, D., Ross, M. and King, C. (2020), "Brand fidelity: scale development and validation”, Journal of Retailing and Consumer Services, Vol. 52, pp. 1-12.

Grewal, D., Iyer, G.R. and Levy, M. (2004), "Internet retailing: enablers, limiters and market consequences", Journal of Business Research, Vol. 57 No. 7, pp. 703-713.

Grewal, D., Iyer, G.R., Krishnan, R. and Sharma, A. (2003), "The internet and the price-value-loyalty chain", Journal of Business Research, Vol. 56 No. 5, pp. 391-398.

Ha, H.Y. and Perks, H. (2005), "Effects of consumer perceptions of Brand experience on the web: brand familiarity, satisfaction and brand trust", Journal of Consumer Behaviour, Vol. 4 No. 6, pp. $438-452$.

Hahn, K.H. and Kim, J. (2009), "The effect of offline brand trust and perceived internet confidence on online shopping intention in the integrated multi-channel context", International Journal of Retail and Distribution Management, Vol. 37 No. 2, pp. 126-141.

Hair, J.F., Black, W.C., Babin, B.J., Anderson, R.E. and Tatham, R.L. (2009), Análisemultivariada de Dados, Bookman Editora.

Hajli, N., Shanmugam, M., Papagiannidis, S., Zahay, D. and Richard, M.O. (2017), "Branding co-creation with members of online brand communities", Journal of Business Research, Vol. 70, pp. 136-144.

Hanson, S., Jiang, L. and Dahl, D. (2019), "Enhancing consumer engagement in an online brand community via user reputation signals: a multi-method analysis", Journal of the Academy of Marketing Science, Vol. 47 No. 2, pp. 349-367.

Hollebeek, L.D., Glynn, M.S. and Brodie, R.J. (2014), "Consumer brand engagement in social media: conceptualization, scale development and validation", Journal of Interactive Marketing, Vol. 28 No. 2, pp. 149-165.

Homburg, C., Schwemmle, M. and Kuehnl, C. (2015), "New product design: concept, measurement, and consequences", Journal of Marketing, Vol. 79 No. 3, pp. 41-56. 
Honea, H. and Horsky, S. (2012), "The power of plain: intensifying product experience with neutral aesthetic context", Marketing Letters, Vol. 23 No. 1, pp. 223-235.

Hossain, M.A., Akter, S. and Yanamandram, V. (2020), "Customer analytics capabilities in the big data spectrum: a systematic approach to achieve sustainable firm performance", in Jain, G., Singh, H., Akter, S., Munjal, A. and Grewal, H.S. (Eds), Technological Innovations for Sustainability and Business Growth, IGI Global, pp. 1-17.

Huang, R. and Sarigöllü, E. (2014), "How Brand awareness relates to market outcome, brand equity, and the marketing mix", In Fashion Branding and Consumer Behaviors, Springer, New York, NY, pp. 113-132.

Iglesias, O., Markovic, S. and Rialp, J. (2019), "How does sensory brand experience influence brand equity? Considering the roles of customer satisfaction, customer affective commitment, and employee empathy", Journal of Business Research, Vol. 96, pp. 343-354.

Iglesias, O., Singh, J.J. and Batista-Foguet, J.M. (2011), "The role of brand experience and affective commitment in determining brand loyalty", Journal of Brand Management, Vol. 18 No. 8, pp. 570-582.

Israeli, A. and Avery, J. (2017), Predicting Consumer Tastes with Big Data at Gap, Harvard Business Case.

Jarvis, C.B., MacKenzie, S.B. and Podsakoff, P.M. (2003), "A critical review of construct indicators and measurement model misspecification in marketing and consumer research", Journal of Consumer Research, Vol. 30 No. 2, pp. 199-218.

Junaid, M., Hou, F., Hussain, K. and Kirmani, A.A. (2019), "Brand love: the emotional bridge between experience and engagement, generation-M perspective", Journal of Product and Brand Management, Vol. 28 No. 2, pp. 200-215.

Kaiser, H.F. and Rice, J. (1974), "Little jiffy, mark IV", Educational and Psychological Measurement, Vol. 34 No. 1, pp. 111-117.

Kawaf, F. and Istanbulluoglu, D. (2019), "Online fashion shopping paradox: the role of customer reviews and Facebook marketing", Journal of Retailing and Consumer Services, Vol. 48, pp. 144-153.

Keller, K.L. (1993), "Conceptualizing, measuring, and managing customer-based brand equity”, Journal of Marketing, Vol. 57 No. 1, pp. 1-22.

Keller, K.L., Parameswaran, M.G. and Jacob, I. (2011), Strategic Brand Management: Building, Measuring, and Managing Brand Equity, Pearson Education India.

Khachatryan, H., Rihn, A., Behe, B., Hall, C., Campbell, B., Dennis, J. and Yue, C. (2018), "Visual attention, buying impulsiveness, and consumer behavior", Marketing Letters, Vol. 29 No. 1, pp. 23-35.

Khan, N., Rahmani, S.H.R., Hoe, H.Y. and Chen, T.B. (2015), "Causal relationships among dimensions of consumer-based brand equity and purchase intention: fashion industry", International Journal of Business and Management, Vol. 10 No. 1, p. 172.

Kim, J., Lee, J. and Choi, D. (2003), "Designing emotionally evocative homepages: an empirical study of the quantitative relations between design factors and emotional dimensions", International Journal of Human-Computer Studies, Vol. 59 No. 6, pp. 899-940.

Klink, R.R. (2003), "Creating meaningful brands: the relationship between brand name and brand mark", Marketing Letters, Vol. 14 No. 3, pp. 143-157.

Klink, R.R. and Athaide, G.A. (2012), "Creating brand personality with brand names", Marketing Letters, Vol. 23 No. 1, pp. 109-117.

Kusumasondjaja, S. and Tjiptono, F. (2019), "Endorsement and visual complexity in food advertising on Instagram”, Internet Research, Vol. 29 No. 4, pp. 659-687.

Ladhari, R., Gonthier, J. and Lajante, M. (2019), "Generation Y and online fashion shopping: orientations and profiles”, Journal of Retailing and Consumer Services, Vol. 48, pp. 113-121.
Online fashion brand recognition

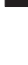


Langner, T., Bruns, D., Fischer, A. and Rossiter, J.R. (2016), "Falling in love with brands: a dynamic analysis of the trajectories of brand love", Marketing Letters, Vol. 27 No. 1, pp. 15-26.

Laroche, M., Kim, C. and Zhou, L. (1996), "Brand familiarity and confidence as determinants of purchase intention: an empirical test in a multiple brand context", Journal of Business Research, Vol. 37 No. 2, pp. 115-120.

Lavie, T. and Tractinsky, N. (2004), "Assessing dimensions of perceived visual aesthetics of web sites", International Journal of Human-Computer Studies, Vol. 60 No. 3, pp. 269-298.

Lee, J.E., Hur, S. and Watkins, B. (2018), "Visual communication of luxury fashion brands on social media: effects of visual complexity and brand familiarity", Journal of Brand Management, Vol. 25 No. 5, pp. 449-462.

Lopez, C. and Fan, Y. (2009), "Internationalisation of the Spanish fashion brand Zara", Journal of Fashion Marketing and Management: An International Journal, Vol. 13 No. 2, pp. 279-296.

Luan, J., Shan, W., Wang, Y. and Xiao, J. (2019), "How easy-to-process information influences consumers over time: online review vs brand popularity", Computers in Human Behavior, Vol. 97, pp. 193-201.

Malhotra, N.K., Kim, S.S. and Patil, A. (2006), "Common method variance in is research: a comparison of alternative approaches and a reanalysis of past research", Management Science, Vol. 52 No. 12 , pp. 1865-1883.

Marken, G.A. (2003), "Emotional branding: how successful brands gain the irrational edge”, Public Relations Quarterly, Vol. 48 No. 2, p. 12.

Martin, B.A. and Strong, C.A. (2016), "The trustworthy brand: effects of conclusion explicitness and persuasion awareness on consumer judgments", Marketing Letters, Vol. 27 No. 3, pp. 473-485.

Mathwick, C., Malhotra, N. and Rigdon, E. (2001), "Experiential value: conceptualization, measurement and application in the catalog and internet shopping environment", Journal of Retailing, Vol. 77 No. 1, pp. 39-56.

Matthes, J., Schemer, C. and Wirth, W. (2007), "More than meets the eye: investigating the hidden impact of brand placements in television magazines", International Journal of Advertising, Vol. 26 No. 4, pp. 477-503.

Melis, K., Campo, K., Lamey, L. and Breugelmans, E. (2016), “A bigger slice of the multichannel grocery pie: when does consumers online channel use expand retailers share of wallet", Journal of Retailing, Vol. 92 No. 3, pp. 268-286.

Merriam-Webster (1993), Merriam-Webster's Collegiate Dictionary, 10th ed., Springfield.

Mugge, R., Dahl, D.W. and Schoormans, J.P. (2018), "What you see, is what you get? Guidelines for influencing consumers' perceptions of consumer durables through product appearance", Journal of Product Innovation Management, Vol. 35 No. 3, pp. 309-329.

Nash, J. (2019), "Exploring how social media platforms influence fashion consumer decisions in the UK retail sector", Journal of Fashion Marketing and Management: An International Journal, Vol. 23 No. 1, pp. 82-103.

Nepomuceno, M.V., Laroche, M. and Richard, M.O. (2014), "How to reduce perceived risk when buying online: the interactions between intangibility, product knowledge, brand familiarity, privacy and security concerns", Journal of Retailing and Consumer Services, Vol. 21 No. 4, pp. 619-629.

O'Cass, A. (2004), "Fashion clothing consumption: antecedents and consequences of fashion clothing involvement", European Journal of Marketing, Vol. 38 No. 7, pp. 869-882.

O'Cass, A. and Siahtiri, V. (2014), "Are young adult Chinese status and fashion clothing Brand conscious", Journal of Fashion Marketing and Management: An International Journal, Vol. 18 No. 3, pp. 284-300.

Park, J. and Stoel, L. (2005), "Effect of brand familiarity, experience and information on online apparel purchase", International Journal of Retail and Distribution Management, Vol. 33 No. 2, pp. 148-160. 
Park, M. and Lennon, S.J. (2009), "Brand name and promotion in online shopping contexts", Journal of Fashion Marketing and Management: An International Journal, Vol. 13 No. 2, pp. 149-160.

Podsakoff, P.M., MacKenzie, S.B., Lee, J.Y. and Podsakoff, N.P. (2003), "Common method biases in behavioral research: a critical review of the literature and recommended remedies", Journal of Applied Psychology, Vol. 88 No. 5, pp. 879-903.

Rahman, M.S. and Mannan, M. (2018), "Consumer online purchase behavior of local fashion clothing brands: information adoption, e-WOM, online Brand familiarity and online brand experience", Journal of Fashion Marketing and Management: An International Journal, Vol. 22 No. 3, pp. 404-419.

Rahman, M.S., Mannan, M., Hossain, M.A. and Zaman, M.H. (2018), "Patient's behavioral intention: public and private hospitals context", Marketing Intelligence and Planning, Vol. 36 No. 3, pp. 349-364.

Rajavi, K., Kushwaha, T. and Steenkamp, J.B.E. (2019), "In brands We trust? A multi-category, multicountry investigation of sensitivity of consumers trust in brands to marketing-mix activities", Journal of Consumer Research, Vol. 46 No. 4, pp. 651-670.

Rossiter, J.R. (2002), "The C-OAR-SE procedure for scale development in marketing”, International Journal of Research in Marketing, Vol. 19 No. 4, pp. 305-335.

Sekaran, U. and Bougie, R. (2011), Business Research Methods: A Skill-Building Approach, John Wiley\& Sons, Chichester.

Spector, P.E. (1994), "Using self-report questionnaires in OB research: a comment on the use of a controversial method", Journal of Organizational Behavior, Vol. 15 No. 5, pp. 385-392.

Sun, J. (2005), “Assessing goodness of fit in confirmatory factor analysis”, Measurement and Evaluation in Counseling and Development, Vol. 37 No. 4, pp. 240-256.

Thomson, M., MacInnis, D.J. and Park, C.W. (2005), "The ties that bind: measuring the strength of consumers' emotional attachments to brands", Journal of Consumer Psychology, Vol. 15 No. 1, pp. 77-91.

Tourangeau, R., Rips, L.J. and Rasinski, K. (2000), The Psychology of Survey Response, Cambridge University Press.

Tractinsky, N. and Lowengart, O. (2007), "Web-store aesthetics in e-retailing: a conceptual framework and some theoretical implications", Academy of Marketing Science Review, Vol. 11, pp. 1-18.

Van Deursen, A.J. and Van Dijk, J.A. (2014), "The digital divide shifts to differences in usage", New Media and Society, Vol. 16 No. 3, pp. 507-526.

Van Grinsven, B. and Das, E. (2016a), "I love you just the way you are: when large degrees of logo change hurt information processing and brand evaluation", In Advances in Advertising Research, Vol. VI, Springer Gabler, Wiesbaden, pp. 379-393.

Van Grinsven, B. and Das, E. (2016b), "Logo design in marketing communications: brand logo complexity moderates exposure effects on brand recognition and brand attitude", Journal of Marketing Communications, Vol. 22 No. 3, pp. 256-270.

Verhellen, Y., Dens, N. and De Pelsmacker, P. (2016), "Do I know you? How brand familiarity and perceived fit affect consumers' attitudes towards brands placed in movies”, Marketing Letters, Vol. 27 No. 3, pp. 461-471.

Vieira, V.A. (2009), "An extended theoretical model of fashion clothing involvement", Journal of Fashion Marketing and Management: An International Journal, Vol. 13 No. 2, pp. 179-200.

Walsh, P., Kim, Y. and Ross, S.D. (2008), "Brand recall and recognition: a comparison of television and sport video games as presentation modes”, Sport Marketing Quarterly, Vol. 17 No. 4.

Washburn, J.H. and Plank, R.E. (2002), "Measuring brand equity: an evaluation of a consumer-based brand equity scale", Journal of Marketing Theory and Practice, Vol. 10 No. 1, pp. 46-62.

Woodside, A.G. and Wilson, E.J. (1985), "Effects of consumer awareness of brand advertising on preference", Journal of Advertising Research, Vol. 25 No. 4, pp. 41-48. 
SJME

24,1

96
Wu, K., Vassileva, J., Zhao, Y., Noorian, Z., Waldner, W. and Adaji, I. (2016), “Complexity or simplicity? Designing product pictures for advertising in online marketplaces", Journal of Retailing and Consumer Services, Vol. 28, pp. 17-27.

Zhang, B. and Kim, J.H. (2013), "Luxury fashion consumption in China: factors affecting attitude and purchase intent”, Journal of Retailing and Consumer Services, Vol. 20 No. 1, pp. 68-79.

\section{Author affiliations}

Muhammad Sabbir Rahman, Department of Marketing and International Business, North South University, Dhaka, Bangladesh

Md Afnan Hossain, School of Management, Operations and Marketing, University of Wollongong, NSW, Australia and Department of Marketing and International Business, North South University, Dhaka, Bangladesh

Md Rifayat Islam Rushan, North South University, Dhaka, Bangladesh

Mohammad Tayeenul Hoque, Department of Marketing and International Business, North South University, Dhaka, Bangladesh, and

Hasliza Hassan, Faculty of Management, Multimedia University Faculty of Management, Cyberjaya, Malaysia

For instructions on how to order reprints of this article, please visit our website: www.emeraldgrouppublishing.com/licensing/reprints.htm

Or contact us for further details: permissions@emeraldinsight.com 